\title{
SECURITY AND DEFENSE COOPERATION AGREEMENT BETWEEN \\ THE ISLAMIC REPUBLIC OF AFGHANISTAN \\ AND \\ THE UNITED STATES OF AMERICA
}

\begin{abstract}
Preamble
The Islamic Republic of Afghanistan (hereinafter, "Afghanistan") and the United States of America (hereinafter, "the United States"), referred to collectively as "the Parties" and singularly as a "Party;"
\end{abstract}

Recognizing the Enduring Strategic Partnership Agreement between the Islamic Republic of Afghanistan and the United States of America, signed May 2, 2012, (the "Strategic Partnership Agreement") and reaffirming that, as recognized in that Agreement, the Parties are committed to strengthen long-term strategic cooperation in areas of mutual interest, including: advancing peace, security, and stability; strengthening state institutions; supporting Afghanistan's long-term economic and social development; and encouraging regional cooperation;

Confirming the recognition in the Strategic Partnership Agreement that cooperation between the Parties is based on mutual respect and shared interests;

Emphasizing also the Strategic Partnership Agreement's recognition that the Parties will go forward in partnership with confidence because they are committed to seeking a future of justice, peace, security, and opportunity for the Afghan people, as well as the reaffirmation of the Parties' strong commitment to the sovereignty, independence, territorial integrity, and national unity of Afghanistan;

Recognizing the enduring partnership between Afghanistan and the United States, and affirming the mutual intent of the Parties to 
expand, mature, promote and further elevate their security and defense cooperation based on this Agreement;

Desiring to continue to foster close cooperation concerning defense and security arrangements in order to strengthen security and stability in Afghanistan, contribute to regional and international peace and stability, combat terrorism, achieve a region which is no longer a safe haven for al-Qaida and its affiliates, and enhance the ability of Afghanistan to deter threats against its sovereignty, security, and territorial integrity; and noting that the United States does not seek permanent military facilities in Afghanistan, or a presence that is a threat to Afghanistan's neighbors, and has pledged not to use Afghan territory or facilities as a launching point for attacks against other countries;

Recalling the Chicago Summit Declaration on Afghanistan, issued on May 21, 2012, by the Heads of State and Government of Afghanistan and Nations Contributing to the North Atlantic Treaty Organization (NATO)-led International Security Assistance Force (ISAF), and specifically, the participants' renewed firm commitment to a sovereign, secure, and democratic Afghanistan and acknowledgment that ISAF's mission will be concluded by the end of 2014 and that their close partnership will continue beyond the end of the transition period including through NATO and Afghanistan's mutual commitment to work to establish a new NATO-led Mission to train, advise, and assist the Afghan National Defense and Security Forces (ANDSF), and noting here that such a mission will also need to be provided with the necessary authorities, status arrangements, and legal basis;

Reaffirming the continued support of the Parties for regional cooperation and coordination mechanisms, with a goal of increasing security and stability by reducing tensions, uncertainty, and misunderstanding;

Recalling the 2013 Consultative Loya Jirga's recognition that this Security and Defense Cooperation Agreement between Afghanistan and the United States is important for the security of Afghanistan;

Desiring to develop further the means of defense and security cooperation between the Parties, based on the principles of full respect for the independence, sovereignty, and integrity of their territories, 
and non-interference in the domestic affairs of each other, in order to promote security and stability in the region, and to combat terrorism;

Agreeing on the importance of cooperative relationships between Afghanistan and its neighbors conducted on the basis of mutual respect, non-interference, and equality and calling on all nations to respect Afghanistan's sovereignty and territorial integrity, and to refrain from interfering in Afghanistan's internal affairs and democratic processes; and

Affirming also that the Parties' cooperation is based on full respect for the sovereignty of each Party, the purposes of the United Nations Charter, and a shared desire to provide a framework for defense and security cooperation between the Parties; and reaffirming their strong commitment to the sovereignty, independence, territorial integrity, and national unity of Afghanistan, as well as respect for Afghan laws, customs, and traditions;

Have agreed as follows: 


\section{ARTICLE 1}

\section{Definitions}

1. "United States forces" means the entity comprising the members of the force and of the civilian component, and all property, equipment, and materiel of the United States Armed Forces present in the territory of Afghanistan.

2. "Member of the force" means any person belonging to the land, sea, or air services of the United States Armed Forces.

3. "Member of the civilian component" means any person employed by the United States Department of Defense (DoD) who is not a member of the force. However, "member of the civilian component" does not mean persons who are permanently resident in Afghanistan or Afghan nationals who normally reside in Afghanistan.

4. "Executive Agent" means Ministry of Defense (MoD) for Afghanistan and DoD for the United States. The Executive Agent serves as the principal contact for its respective Party for the implementation of this Agreement.

5. "United States contractors" means persons and legal entities who are supplying goods and services in Afghanistan to or on behalf of United States forces under a contract or subcontract with or in support of United States forces.

6. "United States contractor employees" means the employees of United States contractors.

7. "Agreed facilities and areas" means the facilities and areas in the territory of Afghanistan provided by Afghanistan at the locations listed in Annex A, and such other facilities and areas in the territory of Afghanistan as may be provided by Afghanistan in the future, to which United States forces, United States contractors, United States contractor employees, and others as mutually agreed, shall have the right to access and use pursuant to this Agreement.

8. "Afghan National Defense and Security Forces" or "ANDSF" means the entity comprising the members of the security forces under the Ministry of Interior and the MoD of Afghanistan and, as 
appropriate, the National Directorate of Security, and other entities as mutually agreed.

9. "Taxes" means all taxes, duties (including customs duties), fees, and similar or related charges of whatever kind, imposed by the Government of Afghanistan which, for the purposes of this Agreement, means by governmental authorities of Afghanistan at any level, including provincial and district levels, and by the agencies of such governmental authorities.

\section{ARTICLE 2}

\section{Purpose and Scope}

1. The Parties shall continue to foster close cooperation to strengthen security and stability in Afghanistan, counter terrorism, contribute to regional and international peace and stability, and enhance the ability of Afghanistan to deter internal and external threats against its sovereignty, security, territorial integrity, national unity, and its constitutional order. Unless otherwise mutually agreed, United States forces shall not conduct combat operations in Afghanistan.

2. To that end, the United States shall undertake supporting activities, as may be agreed, in close cooperation and coordination with Afghanistan, to assist ANDSF in developing capabilities required to provide security for all Afghans, including as may be mutually agreed: advising, training, equipping, supporting, and sustaining ANDSF, including in field engineering, countering improvised explosive devices, and explosive ordnance disposal; establishing and upgrading ANDSF transportation and logistics systems; developing intelligence sharing capabilities; strengthening Afghanistan's Air Force capabilities; conducting combined military exercises; and other activities as may be agreed. The Parties will continue to work on the details of ANDSF development as set forth in the Afghan Program of Record, adopted at the Chicago Summit in 2012, and in the context of the Afghanistan-United States Bilateral Security Consultative Forum.

3. The Parties recognize that ANDSF are responsible for securing the people and territory of Afghanistan. The Parties shall work to enhance ANDSF's ability to deter and respond to internal and external threats. Upon request, the United States shall urgently determine 
support it is prepared to provide ANDSF in order to respond to threats to Afghanistan's security.

4. The Parties acknowledge that U.S. military operations to defeat alQaida and its affiliates may be appropriate in the common fight against terrorism. The Parties agree to continue their close cooperation and coordination toward those ends, with the intention of protecting U.S. and Afghan national interests without unilateral U.S. military counter-terrorism operations. U.S. military counter-terrorism operations are intended to complement and support ANDSF's counterterrorism operations, with the goal of maintaining ANDSF lead, and with full respect for Afghan sovereignty and full regard for the safety and security of the Afghan people, including in their homes.

5. In furtherance of the activities and operations referred to in this Article and for other purposes and missions as may be mutually agreed, and consistent with the authorizations as detailed in this Agreement, United States forces may undertake transit, support, and related activities, including as may be necessary to support themselves while they are present in Afghanistan under the terms of this Agreement, and such other activities as detailed in this Agreement, or as may be mutually agreed.

6. This Agreement, including any Annexes and any Implementing Agreements or Arrangements, provides the necessary authorizations for the presence and activities of United States forces in Afghanistan and defines the terms and conditions that describe that presence, and in the specific situations indicated herein, the presence and activities of United States contractors and United States contractor employees in Afghanistan.

\section{ARTICLE 3}

\section{Laws}

1. It is the duty of members of the force and of the civilian component to respect the Constitution and laws of Afghanistan and to abstain from any activity inconsistent with the spirit of this Agreement and, in particular, from any political activity in the territory of Afghanistan. It is the duty of United States forces authorities to take necessary measures to that end. 
2. The Parties' respective obligations under this Agreement, and any subsequent arrangements, are without prejudice to Afghan sovereignty over its territory, and each Party's right of self-defense, consistent with international law. Cooperation and activities relating to implementation of this Agreement shall be consistent with the Parties' respective commitments and obligations under international law.

3. United States forces shall not enter Afghan homes for the purpose of military operations and searches except under extraordinary circumstances involving the urgent risk to life and limb of U.S. nationals. United States forces shall not arrest or imprison Afghan nationals, nor maintain or operate detention facilities in Afghanistan.

\section{ARTICLE 4}

\section{Developing and Sustaining Afghanistan's Defense and Security Capabilities}

1. With full respect for Afghanistan's sovereignty, the Parties recognize Afghanistan's current requirement for continued international security assistance, and share the goal of Afghanistan taking increasing and, ultimately full, responsibility for funding its defense and security needs and sustaining ANDSF.

2. Afghanistan shall make, consistent with its political and economic stability and its general economic condition, the full contribution permitted by its manpower, resources, and facilities to the development and sustainment of its own defense and security forces. Afghanistan shall take all necessary measures to develop and sustain its defense and security capacities.

3. So long as the Strategic Partnership Agreement so provides, and guided by the pledges set forth at the Chicago Summit in 2012, the United States shall have an obligation to seek funds on a yearly basis to support the training, equipping, advising, and sustaining of ANDSF, so that Afghanistan can independently secure and defend itself against internal and external threats, and help ensure that terrorists never again encroach on Afghan soil and threaten Afghanistan, the region, and the world. The United States shall consult with Afghanistan regarding the amount of funding needed to accomplish the purposes of this Agreement, keeping in mind pledges made in Chicago, and shall take the results of those consultations into 
consideration in executing this obligation. Taking into account Afghanistan's annual priorities, the United States shall direct appropriate funds through Afghan Government budgetary mechanisms, to be managed by relevant Afghan institutions implementing financial management standards of transparency and accountability and procurement, audit, and regulatory oversight in accordance with international best practices.

4. The Parties recognize the importance of ANDSF having the necessary equipment and materiel to secure Afghanistan. To that end, the United States shall continue to cooperate with Afghanistan on providing equipment and materiel for ANDSF.

5. Afghanistan and the United States may cooperate and coordinate with other countries to strengthen ANDSF, as may be mutually agreed, including on equipping ANDSF.

6. In order to contribute effectively to the security of Afghanistan and the region, the United States agrees to cooperate with Afghanistan to continue the development of ANDSF capabilities consistent with Afghanistan's status as a Major Non-NATO Ally.

7. The Parties recognize the benefits for Afghanistan's defense and security to be derived from developing defense capabilities and systems that are consistent with NATO standards and that promote interoperability with NATO. The Parties shall coordinate in the development of Afghanistan's defense and security forces, equipment, materiel, facilities, operational doctrine, and institutions to achieve standardization and interoperability with NATO, in order to promote further the effective utilization and maintenance of defense and security assistance provided to Afghanistan, and to maximize the benefits of cooperation between ANDSF and United States forces. This coordination shall not preclude Afghanistan from procuring independently equipment and materiel for ANDSF from non-NATO countries with its own resources. 


\section{ARTICLE 5 \\ Defense and Security Cooperation Mechanisms}

1. The Parties agree to direct the Afghanistan - United States Working Group on Defense and Security Cooperation, established under the Strategic Partnership Agreement, to:

a. Develop appropriate measures of effectiveness for the analysis and strengthening of Afghanistan's use of available defense and security resources, consistent with the purpose and scope of this Agreement;

b. Complete semi-annual assessments of actual performance against these measures to inform the Parties' respective resource allocation decisions and their cooperation in developing and sustaining Afghanistan's defense capabilities;

c. Develop a process consistent with the purpose and scope of this Agreement, for making timely, accurate, and effective cooperative assessments of internal and external threats to Afghanistan; and

d. Make specific recommendations on enhancing information and intelligence sharing and evaluation.

2. The Parties share the objective of continuing to improve their ability to consult on such threats, including considering how to establish secure or dedicated channels of communication.

\section{ARTICLE 6}

\section{External Aggression}

1. Afghanistan has been subject to aggression and other uses of force inconsistent with the United Nations Charter by foreign states and externally based or supported armed groups. In the context of this Agreement, the Parties strongly oppose such uses of armed force or threats thereof against the territorial integrity or political independence of Afghanistan, including in this regard provision to armed groups of support, such as sanctuary or arms, by any state or other armed groups. The Parties agree to cooperate to strengthen Afghanistan's 
defenses against such threats to its territorial integrity, sovereignty or political independence.

2. The United States shall regard with grave concern any external aggression or threat of external aggression against the sovereignty, independence, and territorial integrity of Afghanistan, recognizing that such aggression may threaten the Parties' shared interests in Afghanistan's stability and regional and international peace and stability.

3. On a regular basis, the Parties shall consult on potential political, diplomatic, military, and economic measures that could form part of an appropriate response in the event of such external aggression or the threat of external aggression against Afghanistan. Consultations shall seek to develop a list of political, diplomatic, military, and economic measures.

4. In the event of external aggression or the threat of external aggression against Afghanistan, the Parties shall hold consultations on an urgent basis to develop and implement an appropriate response, including, as may be mutually determined, consideration of available political, diplomatic, military, and economic measures on the list developed pursuant to paragraph 3 , in accordance with their respective constitutional procedures.

5. The Parties shall develop comprehensive procedures to promote the effective accomplishment of such regular and urgent consultations.

a. Such comprehensive procedures shall recognize consultations involving the participation of the Afghanistan Foreign Minister and the United States Secretary of State, the Afghanistan Defense Minister and the United States Secretary of Defense, and respective Ambassadors in Kabul and Washington, D.C., as primary channels to initiate urgent consultations in the event of external aggression, or threat of external aggression.

b. Such comprehensive procedures shall not, however, limit or prejudice the Parties' ability to consult each other in other channels or through other mechanisms, as urgency or exigency may require.

6. The Parties agree to direct the Afghanistan - United States Working Group on Defense and Security Cooperation to promote the 
effective implementation of this Article, including development of such comprehensive procedures, and review on a regular basis the list of measures developed pursuant to paragraph 3 .

\section{ARTICLE 7}

\section{Use of Agreed Facilities and Areas}

1. Afghanistan hereby provides access to and use of the agreed facilities and areas, as defined in paragraph 7 of Article 1, solely to implement the purpose and scope of this Agreement, taking into account locations of ANDSF and the local Afghan population. Access to and use of such agreed facilities and areas for other purposes shall be as mutually agreed by the Parties.

2. Under this Agreement, Afghanistan hereby authorizes United States forces to exercise all rights and authorities within the agreed facilities and areas that are necessary for their use, operation, defense, or control, including the right to undertake new construction works. United States forces may carry out such construction works with members of the force and the civilian component or by contract.

3. Afghanistan hereby authorizes United States forces to control entry to agreed facilities and areas that have been provided for United States forces' exclusive use, and to coordinate entry with Afghan authorities at joint-use agreed facilities and areas, for the purposes of safety and security. Upon request, the United States shall provide to relevant authorities of Afghanistan access to any agreed facility or area that has been provided for United States forces' exclusive use. The Parties shall establish mutually agreed procedures regarding Afghan authorities' access to any agreed facility or area that has been provided for United States forces' exclusive use. Such procedures and access shall be established with due respect for United States forces operations and security requirements. Acknowledging that United States forces may conduct force protection activities at and in the vicinity of agreed facilities and agreed areas as are necessary, the Parties agree to coordinate and integrate their respective plans for force protection to ensure the safety of United States forces, with full respect for Afghan sovereignty and with full regard for the safety and security of the Afghan people. In furtherance of this objective, United States forces shall not target Afghan civilians, including in their 
homes, consistent with Afghan law and United States forces' rules of engagement.

4. In pursuit of the purpose and scope of this Agreement, in particular United States efforts to train, equip, advise, and sustain ANDSF, Afghanistan shall provide all agreed facilities and areas without charge to United States forces.

5. United States forces shall be responsible for the construction, development, operations, and maintenance costs for agreed facilities and areas provided for their exclusive use, unless otherwise agreed by the Parties. Construction, development, operations, and maintenance costs for agreed facilities and areas provided for joint use, or otherwise used jointly by United States forces and ANDSF or other entities, shall be shared on the basis of proportionate use, unless otherwise agreed.

6. The United States confirms its commitment to respect relevant Afghan environmental and health and safety laws, regulations, and standards in the execution of its policies. United States forces operations and activities on agreed facilities and areas shall be conducted with due regard for the protection of the natural environment and human health and safety, with due respect for applicable Afghan laws and regulations, and in accordance with applicable United States laws and regulations and applicable international agreements.

7. United States forces operations and activities on agreed facilities and areas shall be conducted with full respect for Afghan laws and regulations for the protection of sites or artifacts of historic and cultural heritage. United States forces shall notify and consult immediately with appropriate Afghan authorities through the Joint Commission when sites or artifacts of historic and cultural heritage are discovered on an agreed facility or area. 


\section{ARTICLE 8}

\section{Property Ownership}

1. United States forces shall return to Afghanistan any agreed facility or area, or any portion thereof, including buildings, non-relocatable structures, and assemblies connected to the soil, including those constructed, altered, or improved by United States forces, when no longer needed for United States forces' use. United States forces shall keep the requirement for such agreed facilities and areas under periodic reassessment with a view toward such return. The Parties or their Executive Agents shall consult regarding the terms of return of any agreed facility or area. The Parties agree to pursue a preventative rather than reactive approach to environmental protection and human health and safety. The Parties recognize that the policies and practices of the United States are designed to avoid such damage and endangerment and to apply the more protective of either Afghan or United States standards. In accordance with United States forces policy, United States forces shall take prompt action to address a substantial impact to human health and safety due to environmental contamination that is caused by activities of United States forces and is located on an agreed facility or area.

2. All buildings, non-relocatable structures, and assemblies connected to the soil at the agreed facilities and areas, including those constructed, used, altered, or improved by United States forces, are for the exclusive use of United States forces, United States contractors, and United States contractor employees, and for others as mutually agreed. All such buildings, non-relocatable structures, and assemblies connected to the soil built by United States forces or provided to United States forces for their access and use may be modified by United States forces, and United States forces may use them exclusively until they are no longer required by United States forces.

3. United States forces and United States contractors shall retain title to all equipment, materiel, supplies, relocatable structures, and other movable property they have installed in, imported into, or acquired within the territory of Afghanistan in connection with the presence of United States forces and United States contractors in Afghanistan. The Parties shall consult regarding the possible transfer to or purchase by Afghanistan of equipment determined to be excess, as may be authorized by United States laws and regulations. 


\section{ARTICLE 9 \\ Positioning and Storage of Equipment and Materiel}

1. Afghanistan authorizes United States forces to position the equipment, supplies, and materiel of United States forces within agreed facilities and areas, and at other locations as mutually agreed. United States forces shall maintain title to and control over the use and disposition of such equipment, supplies, and materiel that are stored in the territory of Afghanistan and shall have the right to remove such items from the territory of Afghanistan.

2. The United States confirms its commitment to respect relevant Afghan safety laws, regulations, and standards. United States forces shall take all necessary measures to protect and safely store equipment, supplies, and materiel of United States forces that are of a hazardous nature in accordance with applicable United States laws and regulations. In accordance with United States forces policy, United States forces shall take prompt action (1) to clean up spills located on an agreed facility or area; and, (2) to address a substantial impact to human health and safety due to environmental contamination that is caused by activities of United States forces and is located on an agreed facility or area.

3. The United States, taking into account its obligations under the Convention on the Prohibition of the Development, Production, Stockpiling and Use of Chemical Weapons and on their Destruction, done at Paris on January 13, 1993, and the Convention on the Prohibition of the Development, Production and Stockpiling of Bacteriological (Biological) and Toxin Weapons and on their Destruction done at Washington, London, and Moscow on April 10, 1972, agrees that chemical and biological weapons shall not be stored in the territory of Afghanistan. The Parties affirm that the United States will not position or store nuclear weapons in the territory of Afghanistan. 


\section{ARTICLE 10}

\section{Movement of Vehicles, Vessels, and Aircraft}

1. Afghanistan has full sovereignty over its airspace, territory, and waters. Management of Afghanistan's airspace and transportation shall be exercised through relevant Afghan authorities.

2. With full respect for Afghan sovereignty and consistent with the purpose and scope of this Agreement, Afghanistan authorizes United States government aircraft and civil aircraft that are operated by or exclusively for United States forces to enter, exit, overfly, land, take off, conduct aerial refueling, and move within the territory of Afghanistan. United States government aircraft and civil aircraft that are operated by or exclusively for United States forces shall not be subject to payment of overflight or navigation fees, or landing or parking fees at government-owned airfields, or other charges. United States government aircraft shall be operated with full respect for the relevant rules of safety and movement in Afghanistan, including notification requirements. Civil aircraft being operated by or exclusively for United States forces are subject to notification requirements regarding their entry into and exit from the territory of Afghanistan as required by the civil aviation authorities of Afghanistan.

3. With full respect for Afghan sovereignty and consistent with the purpose and scope of this Agreement, Afghanistan authorizes United States government vessels and vehicles and other vessels and vehicles that are operated by or exclusively for United States forces, to enter, exit, and move within the territory of Afghanistan. All such vessels and vehicles shall be operated with full respect for the relevant rules of safety and movement in Afghanistan. Members of the force and of the civilian component have a duty to respect Afghan motor vehicle regulations when operating official vehicles.

4. United States government aircraft, vessels and vehicles shall be free from boarding without the consent of United States forces authorities. United States government aircraft, vessels, and vehicles shall be free from inspection, regulation, or registration requirements within Afghanistan, except as otherwise provided in this Agreement or as otherwise agreed by the Joint Commission. 
5. United States forces shall pay reasonable charges for services requested and received for United States government aircraft, vehicles, and vessels, free of taxes or similar charges.

6. The Parties agree to establish procedures to implement this Article. The Parties shall review and update, as appropriate, such procedures, and shall address any issues immediately through the Joint Commission that may arise regarding such procedures.

\section{ARTICLE 11}

\section{Contracting Procedures}

1. United States forces, in accordance with United States laws, may enter into contracts for the acquisition of articles and services, including construction, in the territory of Afghanistan. Afghanistan recognizes that United States forces are bound by the laws and regulations of the United States in the solicitation, award, and administration of such contracts. United States forces shall strive to utilize Afghan suppliers of goods, products, and services to the greatest extent practicable, in accordance with United States laws and regulations.

2. United States contractors are subject to registration in Afghanistan, via an expedited process that shall include issuance of a business registration license valid for three years and payment of a reasonable, standard, one-time service charge to the Afghanistan Investment Support Agency as required by the laws and regulations of Afghanistan. United States contractors shall otherwise be exempt from all other Afghan licenses and similar requirements in relation to their entry into or execution of contracts and subcontracts with or on behalf of United States forces.

3. Recognizing the importance of transparency, including through the sharing of information and consultations as may be mutually agreed, United States forces shall give due consideration to concerns and disputes expressed by Afghan authorities regarding United States contractors. The Parties will work together to improve transparency, accountability, and effectiveness of contracting processes in Afghanistan with a view to preventing misuse and bad contracting practices. 
4. Upon the request of either Party, the Parties shall consult immediately through the Joint Commission concerning any issues, including issues concerning the activities of United States contractors and United States contractor employees, that may arise regarding implementation of this Article.

\section{ARTICLE 12}

\section{Utilities and Communications}

1. United States forces may produce and provide services including but not limited to water, electricity, and other utilities for agreed facilities and areas and for other locations as mutually agreed. The production and provision of such services shall be notified to and coordinated with the Joint Commission on a periodic basis. United States forces and United States contractors may use Afghan public water, electricity, and other Afghan public utilities on terms and conditions, including rates or charges, no less favorable than those paid by ANDSF, less taxes or similar or related charges, unless otherwise mutually agreed. United States forces' or United States contractors' costs shall be equal to their proportionate use of such public utilities.

2. Afghanistan recognizes that United States forces shall use the radio spectrum. The Afghan side shall allocate Afghan owned frequencies based on relevant Afghan regulations. The United States shall be allowed to operate its own telecommunications systems (as telecommunication is defined in the 1992 Constitution of the International Telecommunication Union), including the use of such means and services as required to ensure full ability to operate telecommunications systems, and the use of radio spectrum allocated by appropriate Afghan authorities for this purpose. Use of radio spectrum shall be free of cost to the United States.

3. United States forces, in recognition of Afghan ownership and allocation of frequencies within Afghanistan and in the interest of avoiding mutually disruptive interference, shall coordinate with appropriate Afghan authorities for the allocation of frequencies for United States forces present in Afghanistan. United States forces shall respect frequencies in use by or reserved for local operators. 
4. Use of telecommunications by United States forces shall be done in a manner that avoids interference with use of radio spectrum or other telecommunication equipment operated by the Afghan government and other organizations the Afghan government has granted permission to use radio spectrum and/or telecommunications equipment.

\section{ARTICLE 13}

\section{Status of Personnel}

1. Afghanistan, while retaining its sovereignty, recognizes the particular importance of disciplinary control, including judicial and non-judicial measures, by United States forces authorities over members of the force and of the civilian component. Afghanistan therefore agrees that the United States shall have the exclusive right to exercise jurisdiction over such persons in respect of any criminal or civil offenses committed in the territory of Afghanistan. Afghanistan authorizes the United States to hold trial in such cases, or take other disciplinary action, as appropriate, in the territory of Afghanistan.

2. If requested by Afghanistan, the United States shall inform Afghanistan of the status of any criminal proceedings regarding offenses allegedly committed in Afghanistan by the members of the force or of the civilian component involving Afghan nationals, including the final disposition of the investigations or prosecution. If so requested, the United States shall also undertake efforts to permit and facilitate the attendance and observation of such proceedings by representatives of Afghanistan.

3. In the interests of justice, the Parties shall assist each other in investigation of incidents, including the collection of evidence. In investigating offenses, United States authorities shall take into account any report of investigations by Afghan authorities.

4. The United States recognizes the critical role that Afghan law enforcement officials play in the enforcement of Afghan law and order and the protection of the Afghan people. Relevant Afghan authorities shall immediately notify United States forces authorities if they suspect a member of the force or of the civilian component is engaged in the commission of a crime so that United States forces authorities can take immediate action. Members of the force and of the civilian 
component shall not be arrested or detained by Afghan authorities. Members of the force and of the civilian component arrested or detained by Afghan authorities for any reason, including by Afghan law enforcement authorities, shall be immediately handed over to United States forces authorities.

5. Afghanistan and the United States agree that members of the force and of the civilian component may not be surrendered to, or otherwise transferred to, the custody of an international tribunal or any other entity or state without the express consent of the United States.

6. Afghanistan maintains the right to exercise jurisdiction over United States contractors and United States contractor employees.

\section{ARTICLE 14}

\section{Bearing of Arms and Wearing of Uniforms}

1. When present in Afghanistan under this Agreement, members of the force and of the civilian component may possess and carry arms in Afghanistan as required for the performance of their duties and as authorized by their orders. When issuing such orders, United States forces authorities shall consider relevant Afghan officials' views regarding appropriate locations for the presence of arms, including considerations of public safety. In consideration of such views, United States forces shall not, for military operations, enter mosques or other sites of religious significance being used for religious purposes. Members of the force may wear uniforms while in Afghanistan. United States forces authorities shall take appropriate measures to ensure that members of the force and of the civilian component are mindful of their presence in public areas, including in the carrying of weapons.

2. The Parties agree that United States contractors and United States contractor employees are not permitted to wear military uniforms and may only carry weapons in accordance with Afghan laws and regulations.

3. United States contractors performing security services in Afghanistan are subject to all relevant requirements of Afghan laws and regulations. 
4. Upon the request of either Party, the Parties shall consult immediately through the Joint Commission concerning any issues that may arise regarding implementation of this Article.

\section{ARTICLE 15}

\section{Entry and Exit}

1. Members of the force and members of the civilian component may enter and exit Afghanistan at agreed facilities and areas at locations listed in Annex A, at official points of embarkation and debarkation as listed in Annex B, and at other areas as mutually agreed, with identification cards issued by the United States, and either collective or individual movement orders. Passports and visas shall not be required. Such personnel shall be exempt from Afghan law and regulations on registration and control of foreign nationals.

2. United States contractors and United States contractor employees may enter and exit Afghanistan at the places of entry and exit described in paragraph 1 of this Article. Passports and visas shall be required in accordance with Afghan law. If a visa is required, and requested by a United States contractor or a United States contractor employee, it shall provide for multiple entries and exits and shall be valid for a period of not less than one year. The appropriate Afghan authorities may issue or decline to issue required visas expeditiously. In the event Afghanistan declines to issue such visa, the appropriate Afghan authorities shall notify the person concerned and United States forces authorities. For exceptional situations as may be agreed through the Joint Commission, Afghanistan shall seek to put in place and make available to United States contractor employees a process for the issuance of visas upon their arrival in Afghanistan.

3. The United States recognizes the sovereign right of Afghanistan to request the removal of any member of the force or member of the civilian component from Afghanistan. United States forces authorities shall take appropriate measures to remove expeditiously such persons from Afghanistan upon request by proper Afghan authorities.

4. The Parties agree to establish procedures to implement this Article. The Joint Commission shall periodically review and update procedures for appropriate Afghan authorities to process members of the force and of the civilian component who arrive at or depart from 
the places of entry and exit described in paragraph 1 of this Article, including coordination and inspection of documentation. Afghan authorities may develop lists of members of the force and of the civilian component entering and exiting Afghan territory at the agreed facilities and areas, as necessary.

\section{ARTICLE 16}

\section{Importation and Exportation}

1. United States forces and United States contractors may import into, export out of, re-export out of and transport and use in Afghanistan any equipment, supplies, materiel, technology, training, or services. The authorizations in this paragraph do not cover the activities of United States contractors that are not related to the presence of United States forces in Afghanistan. Identifying documents shall be provided to indicate that such equipment, supplies, materiel, technology, training, or services being imported by United States contractors are for United States forces' purposes and not for any private commercial purposes.

2. Members of the force and of the civilian component, United States contractors, and those United States contractor employees who are not Afghan nationals, may import into, export out of, re-export out of and transport and use in Afghanistan personal effects. The imported quantities shall be reasonable and proportionate to personal use. The property referred to in this paragraph may not be sold or otherwise transferred in Afghanistan to persons who are not entitled to import such items duty free unless such transfer is in accordance with agreed procedures, including on payment of any taxes or fees due as a result of such transaction, established by the Joint Commission.

3. United States forces authorities, working with relevant Afghan authorities, shall take appropriate measures to ensure that no items or material of cultural or historic significance to Afghanistan are being exported and that, as provided in United States Central Command General Order Number 1, no alcohol, pornography, illegal narcotics, or privately owned firearms, or other contraband or items as may be mutually agreed, are being imported using the authorizations provided in paragraphs 1 and 2 of this Article. 
4. The importation, exportation, re-exportation, transportation, and use of any articles brought into Afghanistan pursuant to paragraphs 1 and 2 of this Article shall not be subject to restrictions, such as licensing, inspection, or verification, except as provided in this Article, or taxes and customs duties or other charges assessed by government authorities in Afghanistan within the territory of Afghanistan. If Afghan authorities suspect the abuse of the privileges granted in paragraph 2 of this Article to United States contractors and United States contractor employees, then relevant Afghan authorities reserve the right of inspection of such personal effects when arriving or departing from civilian airports in Afghanistan or in personal vehicles at border crossings.

5. The relevant Afghan authorities reserve the right of verification of any container imported by United States contractors and United States contractor employees containing items for United States forces' purposes in Afghanistan or for personal use, as authorized in paragraphs 1 and 2 of this Article. Without causing undue delay, and upon presentation by the relevant Afghan authorities of information to United States forces authorities that a United States contractor is abusing the authority granted in paragraphs 1 or 2 of this Article, United States forces authorities shall open and verify suspected shipments or containers intended for import in the presence of the Afghan authorities. Afghan authorities shall consent to the security requirements of United States forces and upon request by United States forces authorities permit such verifications to take place within agreed facilities and areas or other areas as mutually agreed.

6. Sharing the common goal with Afghanistan of preventing the improper entry into Afghan markets of items imported into Afghanistan under the terms of this Agreement, United States forces authorities shall take measures to prevent abuse of the authorizations in paragraphs 1 and 2 of this Article, and shall conduct inquiries and assist the relevant Afghan authorities in the conduct of inquiries and the collection of evidence relating to the suspected improper importation, exportation, re-exportation, transfer, or disposition of goods by members of the force, members of the civilian component, United States contractors, and United States contractor employees.

7. Items imported into Afghanistan or purchased in Afghanistan pursuant to this Article may be disposed of in Afghanistan with due respect for Afghan laws and regulations. 
8. Upon the request of either Party, the Parties shall review and consult immediately through the Joint Commission concerning any issues that may arise regarding implementation of this Article.

\section{ARTICLE 17}

\section{Taxation}

1. The acquisition in Afghanistan of articles and services by or on behalf of United States forces shall not be subject to any taxes or similar or related charges assessed within the territory of Afghanistan.

2. United States forces, including members of the force and of the civilian component, shall not be liable to pay any tax or similar or related charges assessed by the Government of Afghanistan within the territory of Afghanistan.

3. United States contractors shall not be liable to pay any tax or similar or related charges assessed by the Government of Afghanistan within the territory of Afghanistan on their activities, and associated income, relating to or on behalf of United States forces under a contract or subcontract with or in support of United States forces. However, United States contractors that are Afghan legal entities shall not be exempt from corporate profits tax that may be assessed by the Government of Afghanistan within the territory of Afghanistan on income received due to their status as United States contractors.

4. United States contractors are subject to Afghan requirements regarding employer withholding of personal income tax from United States contractor employees who normally reside in Afghanistan and from United States contractor employees who are Afghan nationals for payment to Afghanistan as required by the laws and regulations of Afghanistan.

5. United States contractor employees who do not normally reside in Afghanistan and United States contractor employees who are not Afghan nationals shall not be liable to pay any tax or similar or related charges assessed by the Government of Afghanistan within the territory of Afghanistan on their activities, and associated income, relating to a contract or subcontract with or in support of United States forces. 
6. United States contractors and United States contractor employees are not exempt under this Agreement from paying taxes assessed by the Government of Afghanistan within the territory of Afghanistan on their activities in Afghanistan that are not associated with supplying goods and services in Afghanistan to or on behalf of United States forces under a contract or subcontract with or in support of United States forces.

\section{ARTICLE 18}

\section{Driving and Professional Licenses}

1. Afghanistan agrees to accept as valid, without a driving test or fee, driving licenses or permits issued by United States authorities to members of the force or of the civilian component, United States contractors, and United States contractor employees for operation of vehicles, vessels, aircraft, or other equipment by or for United States forces within the territory of Afghanistan.

2. Afghanistan agrees to accept as valid all professional licenses issued by United States authorities to members of the force or of the civilian component and United States contractors or United States contractor employees in relation to the provision of services as part of their official or contractual duties.

3. United States forces authorities shall endeavor to ensure that members of the force or of the civilian component, United States contractors, and United States contractor employees have current, valid driving licenses and permits for operation of vehicles, vessels, aircraft, or other equipment by or for United States forces within the territory of Afghanistan. The Joint Commission shall establish mechanisms to exchange information on United States licenses and permits. In response to requests from Afghan authorities, the United States shall seek to verify the validity of such licenses.

\section{ARTICLE 19}

\section{Motor Vehicles}

Afghanistan agrees to accept as valid the registration and licensing by United States forces authorities of the official vehicles of United 
States forces. Upon the request of United States forces authorities, Afghan authorities shall issue, without charge, license plates for United States forces' official, non-tactical vehicles. United States forces' official, non-tactical vehicles shall display official Afghan license plates that are indistinguishable from other Afghan license plates, upon their provision by Afghanistan.

\section{ARTICLE 20}

\section{Service Support Activities}

1. United States forces may directly or through contract establish and operate at agreed facilities and areas service support activities, including military post offices, banking services, military service exchanges, commissaries, recreational service areas, and telecommunications services, including broadcast services. It is not the United States' intention for broadcasting, media, and entertainment services to reach beyond the scope of the agreed facilities and areas. Taking into consideration Afghan laws, traditions, and customs, United States forces may continue to make available television and radio broadcast services such as media and entertainment programming for the purposes of morale, welfare, and recreation of United States forces and other authorized recipients located on agreed facilities and areas.

2. United States forces shall take appropriate measures to limit broadcasting, television programs, media, and entertainment services to authorized recipients and to agreed facilities and areas.

3. Access to service support activities shall be in accordance with United States regulations. United States forces authorities shall adopt appropriate measures to prevent the abuse of such service support activities and the sale or resale of goods or services to persons who are not authorized to patronize such service support activities or providers.

4. No license, permit, or inspection shall be required by Afghanistan for activities connected with such service support activities.

5. The activities, and any organizations undertaking the activities referred to in this Article, are integral parts of United States forces and shall be accorded the same fiscal and customs exemptions granted to 
United States forces, including those provided in Articles 16 and 17 of this Agreement. Such organizations and activities shall be maintained and operated in accordance with applicable United States regulations. Such activities shall not be required to collect or pay taxes or to pay other fees related to their operations. Access to these service support activities shall be restricted to members of the force, members of the civilian component, United States contractors and United States contractor employees, and others as may be authorized.

6. Mail shipped within the United States Military Postal Service transportation system shall be exempt from inspection, search, or seizure by Afghan authorities.

7. The Joint Commission shall periodically review the service support activities and resolve by mutual agreement questions arising in the course of implementation of this Article.

\section{ARTICLE 21 \\ Currency and Exchange}

The Parties agree to establish procedures regarding currency and exchange. The Parties shall review and update, as appropriate, such procedures and shall address any issues immediately through the Joint Commission that may arise regarding such procedures.

\section{ARTICLE 22}

\section{Claims}

1. Each Party waives any and all claims (other than contractual claims) against the other for damage to, loss of, or destruction of its property or injury or death to members of ANDSF or United States forces, and their respective civilian components, arising out of the performance of their official duties in Afghanistan.

2. For claims not excluded under paragraph 1 of this Article, United States forces authorities shall pay just and reasonable compensation in settlement of meritorious third party claims arising out of acts or omissions of members of the force and of the civilian component done in the performance of their official duties and incident to the non- 
combat activities of United States forces. Such claims shall be expeditiously processed and settled by United States forces authorities in accordance with the laws and regulations of the United States and seriously considering the laws, customs, and traditions of Afghanistan.

3. In settling third party claims, United States forces authorities shall take into account any report of investigation or opinion provided to them by Afghan authorities regarding liability or amount of damages.

4. The settlement or adjudication of contract claims shall be carried out in accordance with the terms of the contracts.

5. Upon the request of either Party, the Parties shall consult immediately through the Joint Commission concerning any issues that may arise regarding implementation of this Article.

\section{ARTICLE 23}

\section{Annexes}

Any Annex appended to this Agreement shall form an integral part of this Agreement, and may be amended by written agreement of the Parties.

\section{ARTICLE 24}

\section{Disputes and Implementation}

1. Any divergence in views or dispute regarding the interpretation or application of this Agreement shall be resolved through consultations between the Parties and shall not be referred to any national or international court, tribunal or other similar body, or any third party for settlement.

2. The Parties, or their Executive Agents including through the Joint Commission, may enter into Implementing Arrangements and procedures to carry out the provisions of this Agreement.

3. Cooperation under this Agreement is subject to the relevant laws and regulations of the respective Parties, including applicable appropriations laws. 
4. United States forces authorities shall pay reasonable, fair market charges, minus any taxes, for goods or services they request and receive.

\section{ARTICLE 25}

\section{Joint Commission}

1. The Parties hereby establish a Joint Commission to oversee implementation of this Agreement. The Joint Commission shall be co-chaired by representatives of the Executive Agents. The Joint Commission may include other governmental representatives requested by the Executive Agents and appointed by the Parties.

2. The Joint Commission shall determine its own procedures and arrange for such auxiliary organs, including the establishment of Working Groups and administrative services, as may be considered appropriate. Each Executive Agent shall bear the costs of its participation in the Joint Commission.

3. The Joint Commission shall coordinate and exchange information, as appropriate, with the Afghanistan - United States Working Group on Defense and Security Cooperation established under the Strategic Partnership Agreement.

\section{ARTICLE 26 \\ Entry into Force, Amendment, and Termination}

1. This Agreement shall enter into force on January 1, 2015, after the Parties notify one another through diplomatic channels of the completion of their respective internal legal requirements necessary for the entry into force of this Agreement. It shall remain in force until the end of 2024 and beyond, unless terminated pursuant to paragraph 4 of this Article.

2. This Agreement, upon its entry into force, shall supersede the exchange of notes dated September 26, 2002, December 12, 2002, and May 28, 2003, regarding the status of United States forces in Afghanistan. This Agreement shall also supersede any prior 
agreements and understandings which the Parties mutually determine, through a subsequent exchange of diplomatic notes, to be contrary to the provisions of this Agreement.

3. This Agreement may be amended by written agreement of the Parties through the exchange of diplomatic notes.

4. This Agreement may be terminated by mutual written agreement or by either Party upon two years' written notice to the other Party through diplomatic channels. Termination of any Annex to or Implementing Arrangement under this Agreement does not result in termination of this Agreement. Termination of this Agreement in accordance with this paragraph shall, without further action, result in termination of all Annexes and Implementing Arrangements.

IN WITNESS WHEREOF, the undersigned, being duly authorized by their respective Governments, have signed this Agreement.

DONE at Kabul, this $30^{\text {th }}$ day of September 2014 in duplicate, in the Pashto, Dari, and English languages, each text being equally authentic.

FOR THE ISLAMIC

REPUBLIC OF

FOR THE UNITED STATES

AFGHANISTAN: OF AMERICA:

H.E. Mohammed Haneef Atmar

H.E. James B. Cunningham

National Security Advisor of the Ambassador of the

Islamic Republic of Afghanistan United States of America 


\begin{abstract}
ANNEX A
List of Locations in Afghanistan of Afghan Facilities and Areas Provided by Afghanistan for United States Forces Access and Use ("Agreed Facilities and Areas")
\end{abstract}

Kabul

Bagram

Mazar-e-Sharif

Herat

Kandahar

Shorab (Helmand)

Gardez

Jalalabad

Shindand

Agreed facilities and areas also include other facilities and areas, if any, of which United States forces have the use as of the effective date of this Agreement and other facilities and areas at other locations in Afghanistan as may be agreed and authorized by the Minister of Defense. 


\section{ANNEX B \\ Official Points of Embarkation and Debarkation}

Bagram Airbase

Kabul International Airport

Kandahar Airbase

Shindand Airbase

Herat International Airport

Mazar-e-Sharif Airport

Shorab (Helmand)

Land Ports:

Toorkham, Nangarhar Province

Spinboldak, Kandahar Province

Toorghundi, Herat Province

Hairatan, Balkh Province

Sherkhan Bandar, Kunduz Province

Other official points of embarkation and debarkation as may be mutually agreed. 